Vol.16, No. 59, April 2021, 223-235

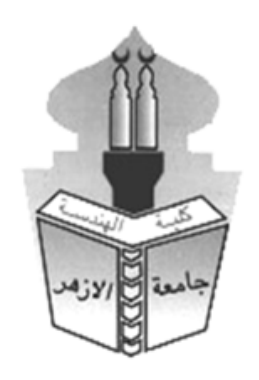

\title{
INUNDATION HAZARDS ON NILE DOWNSTREAM COUNTRIES DUE TO GERD BREAK
}

\author{
Mohammed I. Idress", Bakenaz A. Zeidan*, Fahmy S. Abdelhaleem ${ }^{* *}$ \\ *Irrigation and Hydraulics Engineering Department, Faculty of Engineering, Tanta \\ University, Egypt. \\ **Civil Engineering Department, Benha Faculty of Engineering, Benha University, Egypt. \\ *Corresponding Author's E-mail: mohamed.edress@,f-eng.tanta.edu.eg
}

\begin{abstract}
Flood due to Dam break can cause a huge loss to human life and property on the downstream area. This loss to human life and property depended on extent of inundation area, size of population at risk, the propagation of flood waves and the amount of warning time available. This paper presents flood hazards on Sudan and Egypt due to Grand Ethiopian Renaissance Dam (GERD) break. The GERD is located at $20 \mathrm{~km}$ upstream of the Ethiopian-Sudaness border on Blue Nile River. GERD break may be occurred due to many different reasons such as structural instability, overtopping and seepage. Earthquakes, landslide and sabotage can be leads to insidious GERD break. Outflow hydrographs due to GERD break were obtained by HEC-RAS model. The Blue Nile and the Nile River downstream of GERD until the AHD is simulated using SOBEK 1D-2D model. The related data were collected to simulate and analyze GERD break hazard. A risk assessment of the GERD break is obtained. The flood wave propagation is found in terms of inundations maps. The flood water levels and arrival time downstream GERD to AHD is achieved. The results of this investigation could be used to help decision makers to prepare an emergency plan and warning systems to rescue the affected downstream area and to put an evacuate plan.
\end{abstract}

\section{KEYWORDS: Flood hazards, GERD, AHD, numerical modeling, inundation}

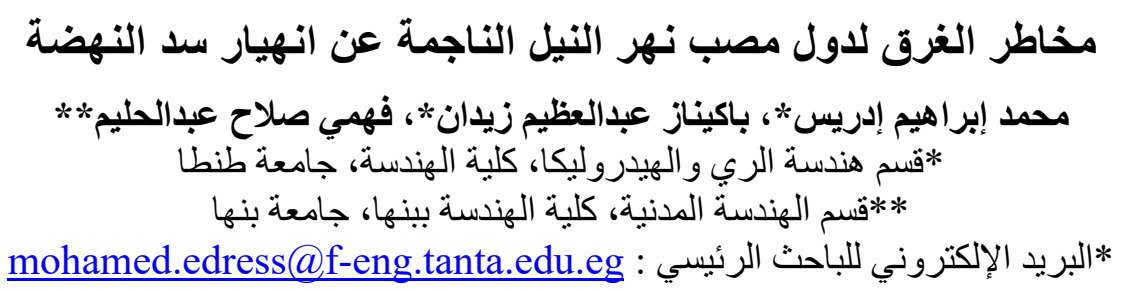

إنهيار السدود من الممكن أن تتسبب في تولا فيضانات مدمره لما هو خلفها من مساحات، والتي من الممكن أن بتولد عنها

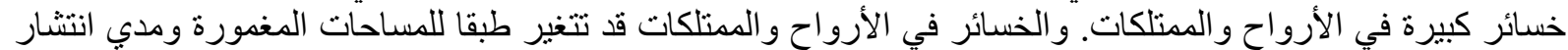

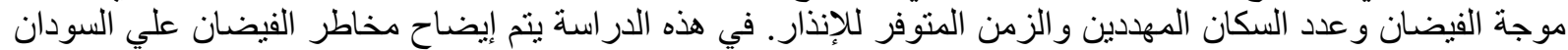

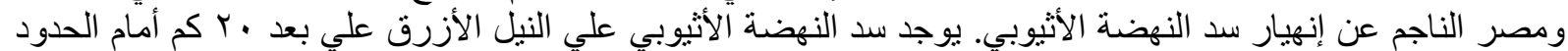
السودانية الأثيوبية. يوجد عدد من الأسباب لإنهيار سد النهضة الأثيوبي ومنها عدم الاتزان الإنشائي أو تدفق المياه من أعلي التي

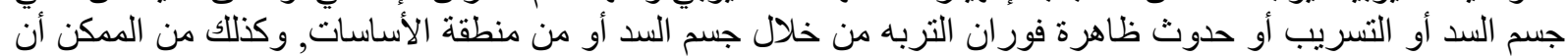

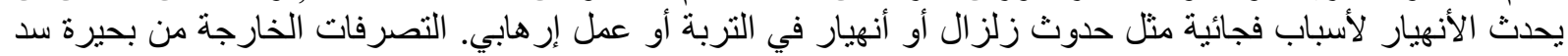


النهضة نتيجة الانهيار نم حسابها باستخدام برنامج HEC-RAS. تم تمثيل نهر النيل الأزرق ونهر النيل خلف سد النهضة

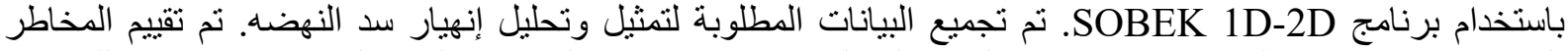

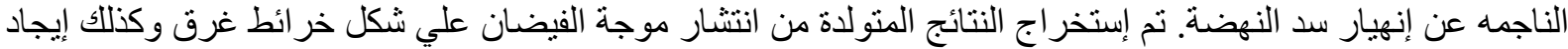

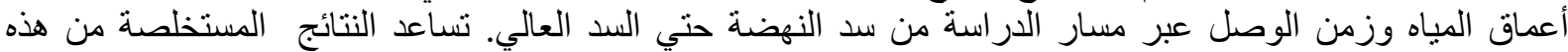

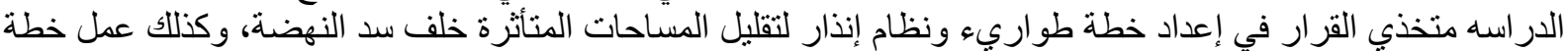

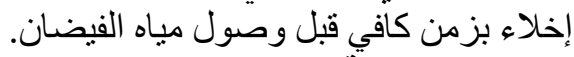
الكلمات المفتاحيةّة : مخاطر الفيضانات, سد النهضئة النهان, السد العالمي, النمذجة العددية, الغرق

\section{INTRODUCTION}

The Nile River is an international river, shared by eleven riparian countries. It has many tributaries as shown in Fig. 1. The White Nile is originated from the Kagera, which drains the mountains of Burundi and Rwanda and flows to Victoria Lake. The outflow from Victoria lake is flow through many lakes, swamp, river and tributaries to confluence at Khartoum with the Blue Nile (Sutcliffe \& Parks, 1999). The Blue Nile is the major tributary of the Nile River. It begins at Tana Lake in the Ethiopian plateau and flows to Sudan. The Atbara River is one of main tributary of the Nile River system, its flows from the Ethiopian plateau and confluence the Nile River at Atbara, north of Khartoum. The Nile River flow arrive Aswan has contributes about $85 \%$ from the Ethiopian headwater, the remaining of $15 \%$ coming from the White Nile.

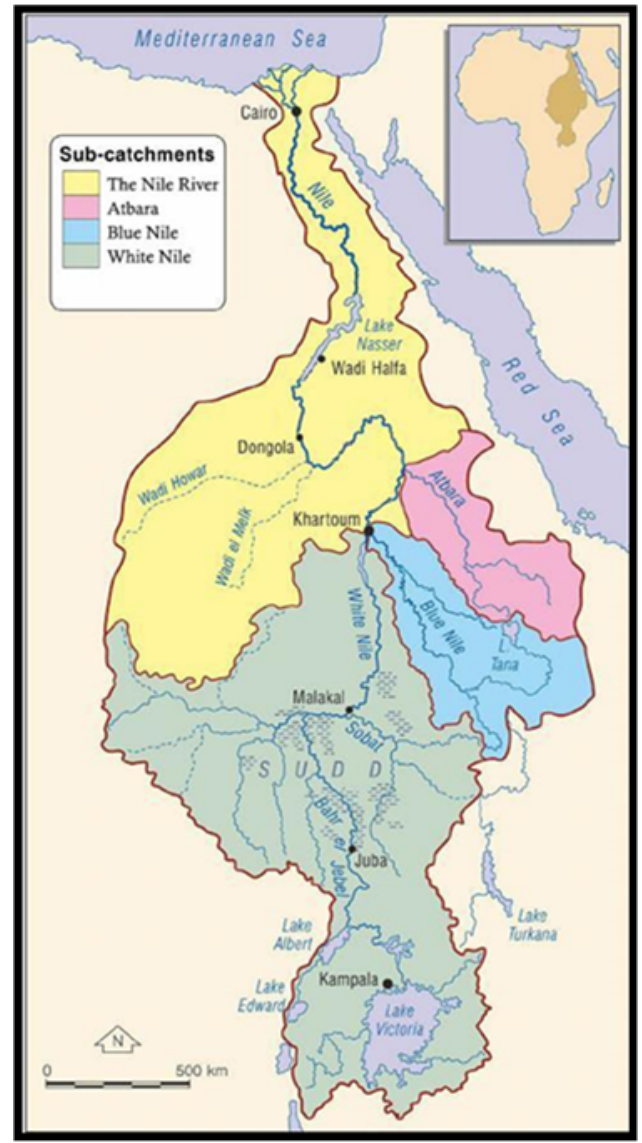

Fig. 1 The Nile River tributaries

The Nile River water is controlled by many dams, such as Rossieres, Sennar, Jebel Aulia, Khashm El Girba, Merowe and AHD. These dams provide water storage and flow regulation, hydropower and protection from severe floods and droughts. The flood due to dam failure causes a huge loss to human life and property. The loss of human life and property occurred due to dam break would vary with size of population at risk, extent of inundation area, and the 
amount of warning time available. Planning the emergency and evacuation plan to reduce dam break hazards required many predictions as the dam break floods, the inundated area, propagation of the flood waves, the flow velocity, the flood depth and the travel time of the flood waves along study area. The main objective of this study is to depict the flood hazards due to GERD break on the area bounded by GERD and the AHD.

Soliman et al. (2019) divided the area between GERD and AHD to six separated reaches. The modelling of GERD break shows that, the peak outflow is $2000000 \mathrm{~m} 3 / \mathrm{s}$ and occurred within $5 \mathrm{hr}$ from the beginning of break. The peak inflow of AHD reservoir approached $37000 \mathrm{~m} 3 / \mathrm{s}$ after 3 weeks from the beginning of GERD break. The Khartoum will be covered by water depth up to $15 \mathrm{~m}$, above the ground level, within 4 days from the beginning of GERD break. AHD affected by GERD failure depends on the water level in its reservoir at the time of GERD break. Khosravi et al. (2019) analysed flood hazards due to Sefied Roud Dam, which is located in Giulan province in Iran. This dam is a buttress gravity dam, with $106 \mathrm{~m}$ height, crest length of $425 \mathrm{~m}$, and $8 \mathrm{~m}$ width. The reservoir of this dam has a storage capacity of 1.2 billion cubic meters (BCM). The disaster area considered in this study was $21 \mathrm{~km}$ downstream of the dam body. The methodology of study consisted of two steps; the first one was to defined the flood hydrograph by using HEC-RAS, and the other one was to estimate a 2D inundation map by RAS-map. Juliastuti \& Setyandito (2017) developed a flood modelling to find the inundation map for Krisak dam in Indonesia. The dam type is a homogenous earth dam. The height of Krisak dam is $20 \mathrm{~m}, 350 \mathrm{~m}$ length and the effective reservoir storage is 2.7 $\mathrm{BCM}$. The spillway is free flow ogee and its length is $33 \mathrm{~m}$. A numerical dam break model of Zhong Xing HY-21 was applied. The overtopping and piping failure are assumed as a mode of Krisak dam failure. Asnaashari et al. (2013) applied the combined of HEC-RAS model with Geographic Information System (GIS) to define the breach scenarios for two dams in British Columbia at Canada. The HEC-GeoRAS and ArcGIS were employed to generate the flood inundation maps of the study dam failure. El Bastawesy et al. (2015) simulated the GERD reservoir using SRTM3-DEM. They defined the water level, water depth, reservoir surface area, reservoir storage of GERD. Abdelhaleem et al. (2011) assessed the risk of AHD breaching due to overtopping and piping numerically by using HR BREACH model. They believed that the breach developed progressively in $95 \mathrm{hr}$ and reached a depth of $62.11 \mathrm{~m}$, and a width of $666.30 \mathrm{~m}$ at level of $133.89 \mathrm{~m}+\mathrm{msl}$. The resulting flood wave propagations downstream of the AHD were also simulated by applying SOBEK 1D-2D model. They stated that the first propagation wave takes about $143 \mathrm{hr}$ to travel a distance of $953 \mathrm{~km}$ downstream the AHD. Mahdi (2007) used the National Weather Service breach model (NWS-Breach) to estimate the flood hydrograph of the Bovilla Dam due to the piping failure. This dam is an earth fill dam with $81 \mathrm{~m}$ high and located in in Albania, South Eastern Europe.

Assesing the risk hazards due to GERD break is depends on creating inundation maps and defining the flood depth, time arrival and flow velocity at main structure and cities downstream the dam. This paper aims to assess hazards of inundation due to GERD break on Sudan and Egypt, numerically. Many roads, hospital, airport, schools, railway, police and fire station are exepected to be out of service due to this break. 15 milion of Sudanese live on the bank of Blue Nile River and the Nile River threatening to lose their lives and their homes. Many of Cattle heads will be losed. $600000 \mathrm{~km} 2$ of Sudan area is expected to be inundated.

\section{STUDY AREA AND DATA COLLECTION}

The area bounded by the GERD and AHD is considered as the study area to estimate flood hazards due to GERD break, Fig 2. The study area is $640000 \mathrm{~km} 2$ with $225 \mathrm{~km}$ as an average width along the Blue Nile and the Nile River. The area of is loctaed in Sudan and Egypt. The dams in the study area are Roseires dam, which located in Sudan with 6.8 BMC at level 490 $\mathrm{m}+\mathrm{msl}$ (Shahin, 1985). The dam consists of five sluice gates with $6 \mathrm{~m}$ wide and $10.5 \mathrm{~m}$ high at an invert level of $438.5 \mathrm{~m}+\mathrm{msl}$. It is spillway was constructed using 10 radial gates with 12 $\mathrm{m}$ width by $10 \mathrm{~m}$ high at a crest level of $466.7 \mathrm{~m}+\mathrm{msl}$, (Ali, 2014). Sennar dam is located at $350 \mathrm{~km}$ south Khartoum city, with a storage capacity of $0.93 \mathrm{BMC}$ at $420 \mathrm{~m}+\mathrm{msl}$. The dam contains eighty low level sluices with $2 \mathrm{~m}$ wide and $8.4 \mathrm{~m}$ height at an invert level 404 $\mathrm{m}+\mathrm{msl}$. It has also 112 spillways at higher level with variable wide ranged from 3 to $5 \mathrm{~m}$ at an invert level at $417 \mathrm{~m}+\mathrm{msl}$, (Ali, 2014). Merowe dam is located about $350 \mathrm{~km}$ north of Khartoum city and the operation of this dam started in 2009. The dam is about $9.2 \mathrm{~km}$ long. 
Its reservoir has $12.4 \mathrm{BCM}$ storage at level of $300 \mathrm{~m}+\mathrm{msl}$. The spillway of this dam consists of two surface gates at $280.50 \mathrm{~m}+\mathrm{msl}$ and 12 low level sluices at elevation of $264 \mathrm{~m}+\mathrm{msl}$. The considered study area ended by the AHD which is located at $6.50 \mathrm{~km}$ south of the Aswan Old Dam (AOD) in Aswan city, Egypt. Its reservoir has a maximum capacity of 162 BCM corspondes to water level of $182 \mathrm{~m}+\mathrm{msl}$ (Abdelhaleem et al. 2011).

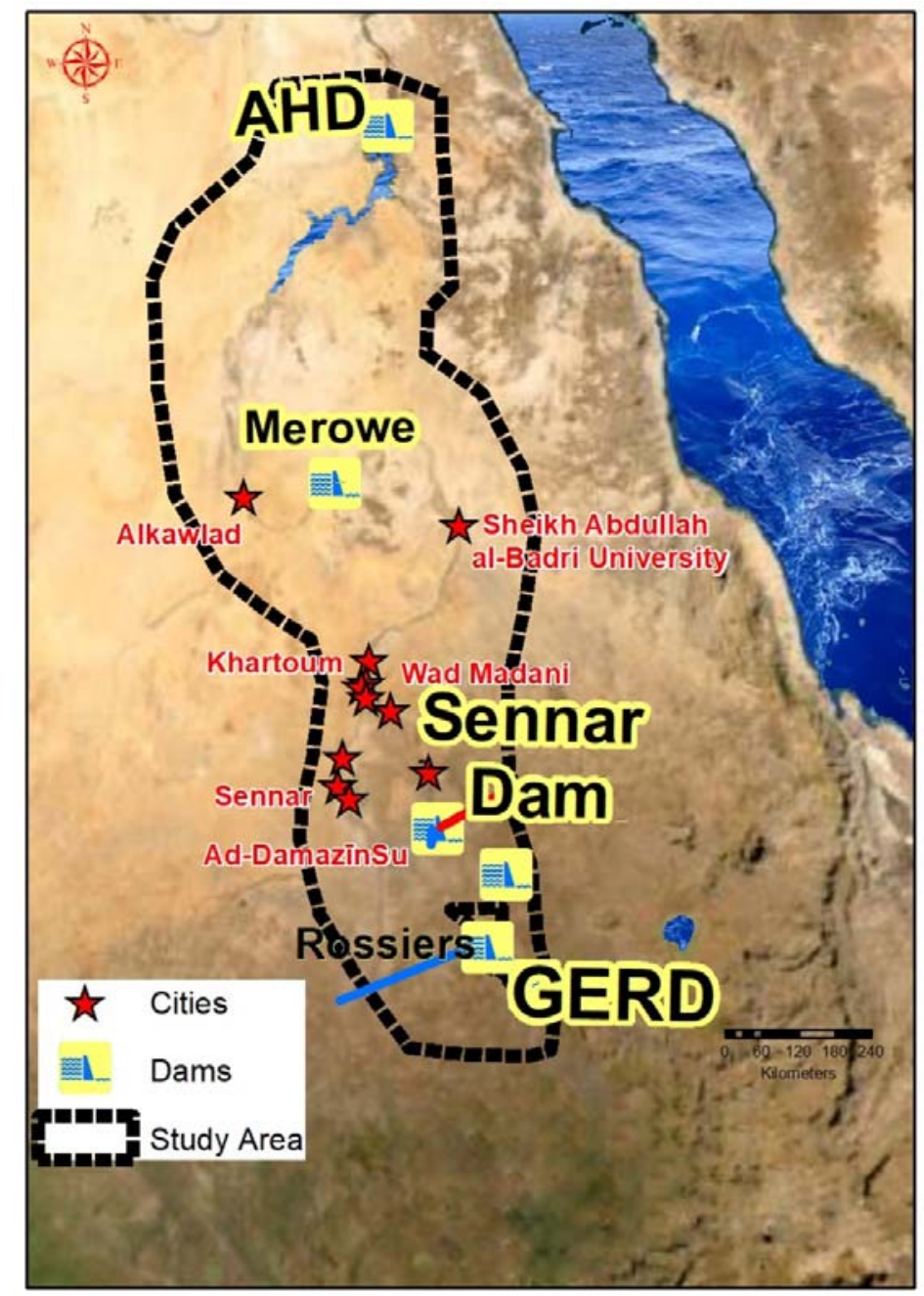

Fig. 2 Study area

The study area starts with the GERD, which is located $20 \mathrm{~km}$ upstream Ethiopian-Sudanans borders on the Blue Nile, as shown in Fig 3. GERD is still under construction since 2011, it consists of two dams, a main dam and a saddle dam. The main dam is a roller compacted concrete dam, with $145 \mathrm{~m}$ height and $1780 \mathrm{~m}$ length. The saddle dam is a Rock fill dam, with a bituminous surface sealing. It has $45 \mathrm{~m}$ height and $4800 \mathrm{~m}$ long. The crest level of the dam is $644 \mathrm{~m}+\mathrm{msl}$. its reservoir has 640 and $590 \mathrm{~m}+\mathrm{msl}$ as a full and minimum supply level respectively. The total storage of the reservoir is $74 \mathrm{BCM}$. The reservoir storage is divide into live and dead storages as 59.22 $\mathrm{BCM}$ and $14.78 \mathrm{BCM}$, respectively. The reservoir area at full supply level will cover $1874 \mathrm{~km} 2$ and $606 \mathrm{~km} 2$ at minimum level, (Sayed et al., 2013). Based on the available information about GERD, the total power generated by dam turbine is of $6000 \mathrm{MW}$ with $350 \mathrm{MW}$ capacity. The GERD reservoir outflow is ranged between 3600 to $3800 \mathrm{~m} 3 / \mathrm{s}$, depited of the measured inflow of Rosaries reservoir, which ranged between 200 $\mathrm{m} 3 / \mathrm{s}$ and $6500 \mathrm{~m} 3 / \mathrm{s}$ (Tesfa, 2013). 


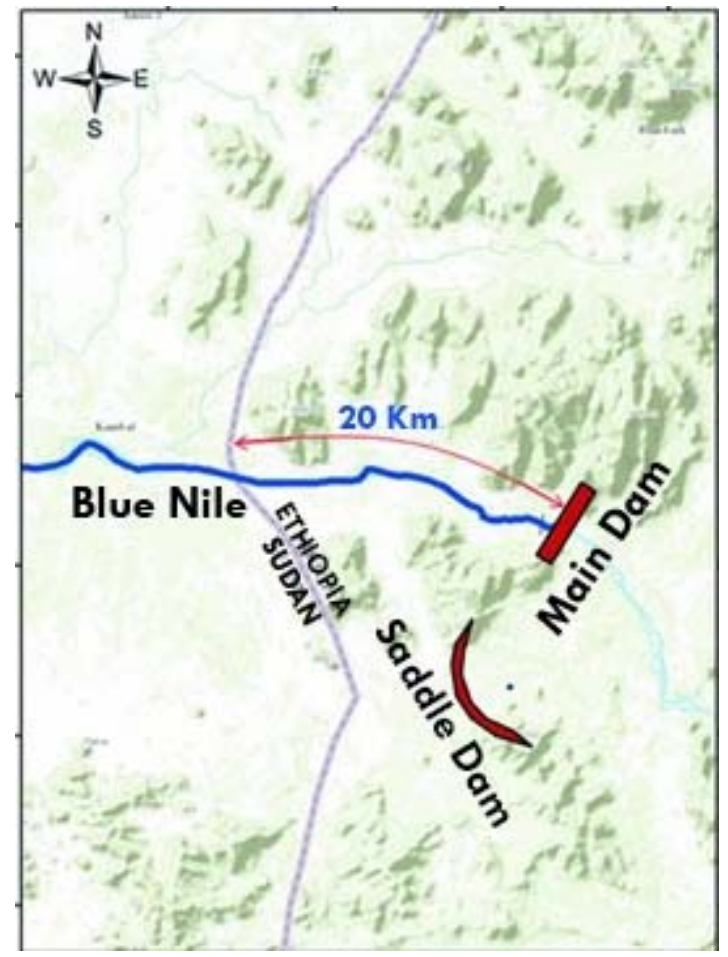

Fig. 3 GERD location (Soliman et al., 2019)

\section{SOBEK Model}

SOBEK Rural-1D combined with SOBEK overland-2D were used for simulating the Blue Nile River from GERD to Khartoum and Nile River from Khartoum to AHD as 1D and the study area as 2D. Basic equations used for SOBEK Rural-1D is full Saint-Venant equations. This is based on continuity and momentum equations. Substitute friction slope in momentum equation by discharge, Chezy coefficient, section geometric properties and the Boussinesq leads momentum equation to be written as:

$\frac{\partial Q}{\partial t}+\frac{\partial}{\partial x}\left(\alpha_{B} \frac{Q^{2}}{A}\right)+g A \frac{\partial h}{\partial x}+\frac{g Q|Q|}{C^{2} R A}=0$

where $\mathrm{C}=$ Chezy coefficient, $\left(\mathrm{L}^{0.5} \mathrm{~T}^{-1}\right)$.

$\mathrm{g}=$ gravitational acceleration, $\left(\mathrm{LT}^{-2}\right)$.

$\mathrm{h}=$ water level relative to reference level, $(\mathrm{L})$.

$\mathrm{Q}=$ discharge, $\left(\mathrm{L}^{3} \mathrm{~T}^{-1}\right)$.

$\mathrm{R}=$ hydraulic radius, $(\mathrm{L})$.

$\mathrm{T}=$ time, $(\mathrm{T})$.

$\mathrm{x}=$ distance along the channel, $(\mathrm{L})$.

$\alpha_{\mathrm{B}}=$ Boussinesq coefficient, (-).

The flow in SOBEK overland-2D is described by three equations as the continuity equation, the momentum equation for the x-direction and the momentum equation for the y-direction. The continuity equation can be written as:

$\frac{\partial \xi}{\partial t}+\frac{\partial(u h)}{\partial x}+\frac{\partial(v h)}{\partial y}$

For two-dimensional flow, two momentum equations are calculated, together with the continuity equation. The momentum equations can be written as:

$\frac{\partial u}{\partial t}+u \frac{\partial u}{\partial x}+v \frac{\partial u}{\partial y}+g \frac{\partial \xi}{\partial \mathrm{x}}+g \frac{u|V|}{C^{2} h}+a u|u|=0$ 
$\frac{\partial v}{\partial t}+u \frac{\partial v}{\partial x}+v \frac{\partial v}{\partial y}+g \frac{\partial \xi}{\partial y}+g \frac{v|V|}{C^{2} h}+a v|v|=0$

where: $\mathrm{u}=$ velocity in $\mathrm{x}$-direction, $\left(\mathrm{LT}^{-1}\right)$

$\mathrm{V}=$ velocity in $\mathrm{y}$-direction, $\left(\mathrm{LT}^{-1}\right)$

$\mathrm{V}=$ velocity $=\left(\mathrm{u}^{2}+\mathrm{v}^{2}\right)^{0.5}$. $\left(\mathrm{LT}^{-1}\right)$

$\zeta=$ water level above plane of reference, $(\mathrm{L})$

$\mathrm{d}=$ depth below plane of reference, $(\mathrm{L})$

$\mathrm{h}=$ total water depth $=\zeta+\mathrm{d},(\mathrm{L})$

These equations are solved numerically using the Delft-scheme. This scheme solves the De Saint-Venant equations a staggered grid. In this staggered grid the water levels are defined at the connection nodes and calculation points, while the discharges are defined at the intermediate reaches or reach segments.

\section{STUDY METHODOLOGY}

The hazards due to GERD break on Sudan and Egypt are investigated theough a procedure as depicts in Fig 4. To start this study, its required to collect a various forms of data, such as, cross sections along the Blue Nile River and the Nile River, and 30-m Digital Elevation Model, DEM were created. Discharge and water levels were collected at various gauge stations and at the main structures along the study area. After data collection, 1D numerical model is developed and calibrated. Suitable DEM used as grid to couple the 1D with 2D model. Time step and simulation period is selected to process the model. The output results are presented in table, chart and maps.

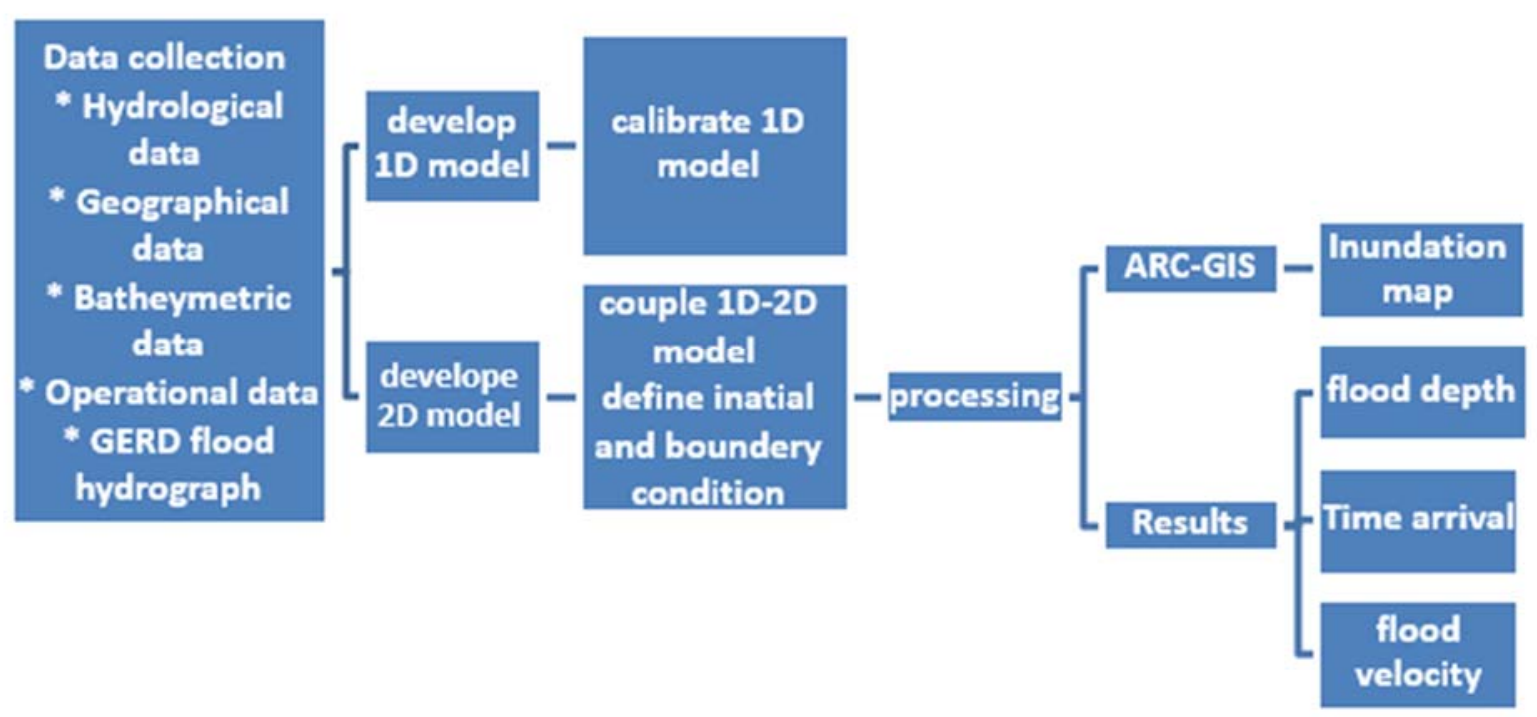

Fig 4 Study methodology

\section{MODEL SCHEMATIZATION}

The study reach described by 480 cross sections, calculation nodes. the inflow points is used to simulate White Nile and Atbra River, and structure points is used to define Roseires, Sennar and Merowe dams. Also, boundery and inatial piont is used to defin the inatial and boundery condition. The model schematization is shown in Fig 5. 


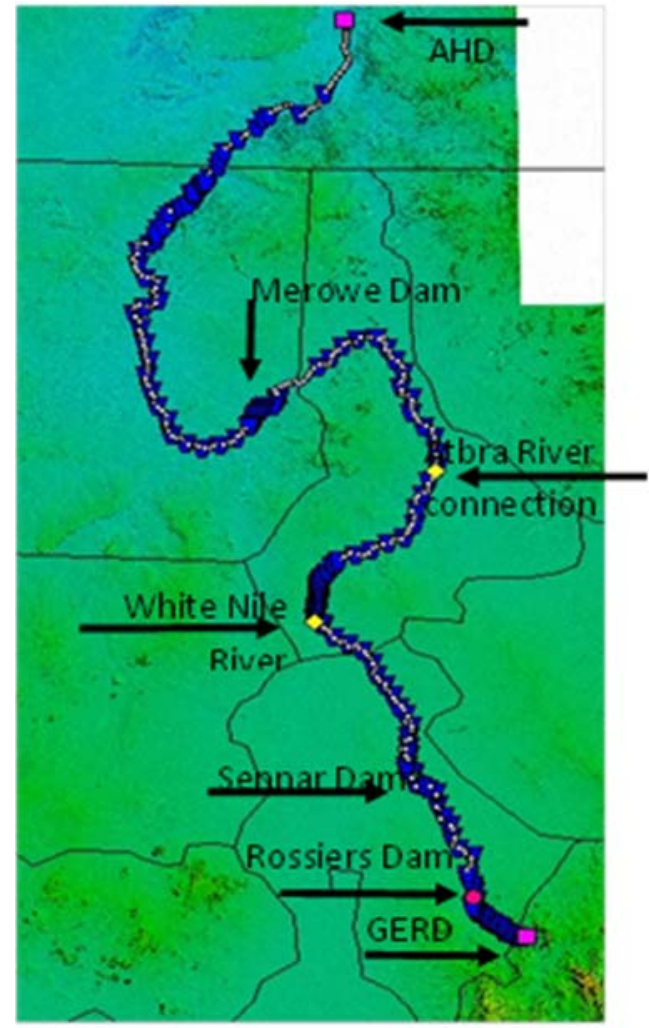

Fig 5 Model schematization

\section{CALIBRATION MODEL}

Calibrations of the 1D model done based on field measurements of dam resrvoirs inflows, outflow, water levels upstream and downstream dams. The calibration were performed by comparing the simulation results with theose measured values at the main dam (various gauge stations at study area were recoreded). Several model runs were made to achieve the best agreement between measured and computed values from the model. This was carried out by adjusting the roughness coefficients at various locations along the modeled reaches. The opening of Roseires, Sennar River and Merowe dams and the inflow of White Nile and the Atbra River were considered during calibration process.

The comparsion between the computed water level and the measured ones is shown in Fig 6, a good agreement between them is observed.

The measured upstream and downstream water levels at Rossiers dam at the third of August 2010 were 469 and $449 \mathrm{~m}+\mathrm{msl}$, respectively, and the corrsponding simulated water levels upstream and downstream Rossiers dam were 468.6 and $448.3 \mathrm{~m}+\mathrm{msl}$, respectively. The difference between the upstream measured and computed water levels were about $0.40 \mathrm{~m}$, for the downstream was $0.70 \mathrm{~m}$. The measured upstream and downstream water level of Sennar dam at the third of August 2010 were 417 and $411 \mathrm{~m}+\mathrm{msl}$, respectively. The corrsponding computed water levels upstream and downstream Sennar dam were 417 and $410 \mathrm{~m}+\mathrm{msl}$. The difference between the upstream measured and the computed water levels were about $0.00 \mathrm{~m}$, for the downstream is $1.00 \mathrm{~m}$. The measured upstream and downstream water levels of Merowe dam at the first of September 2010 were 292 and $252.5 \mathrm{~m}+\mathrm{msl}$, respectively. The corrsponding simulated water levels upstream and downstream Merowe dam were 292 and $260 \mathrm{~m}+\mathrm{msl}$, respectively. The difference between the upstream measured and the computed water levels were about $0.00 \mathrm{~m}$, for the downstream was $7.50 \mathrm{~m}$. The measured upstream water level of AHD at the second of September 2010 were $175 \mathrm{~m}+\mathrm{msl}$. the corrsponding simulated water levels upstream AHD was 174.8. The difference between the upstream measured and the computed water levels were about $0.20 \mathrm{~m}$. the abovementioned comparsion between measured and computed water levels reveal that the numerical model simultes the studied reach well. 


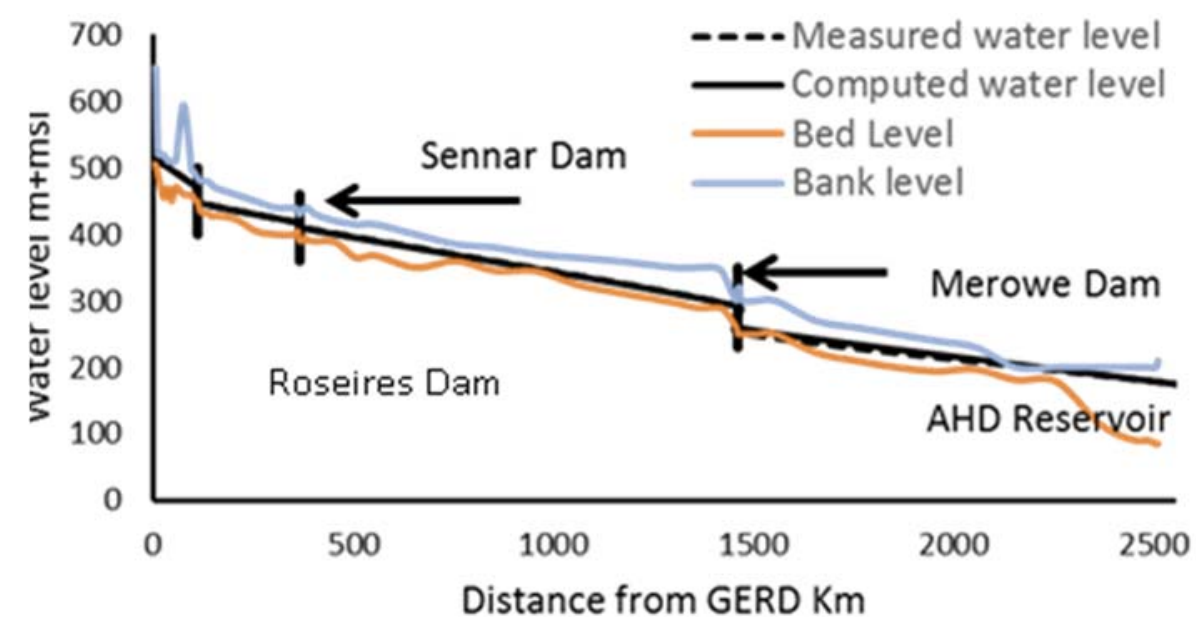

Fig 6 Model calibration

\section{INITIAL and BOUNDARY CONDITION}

Idress et al. (2018) developed 15 scenarios for the flood hydrograph due to GERD break. The worst flood hydrograph take place in case of 5 hours full formation time. This scenario is selected in this study as an initial condition for the model, Fig 7. Upstram water level of the AHD was considered as downstream boundary condition $(174 \mathrm{~m}+\mathrm{msl})$. Simulation time is 120 days discretized into a day as incremental time steps. White Nile and Atbara are simulated in this model as lateral inflow to the model with constant discharges as $1000 \mathrm{~m} 3 / \mathrm{s}$ and $1530 \mathrm{~m} 3 / \mathrm{s}$, respectively.

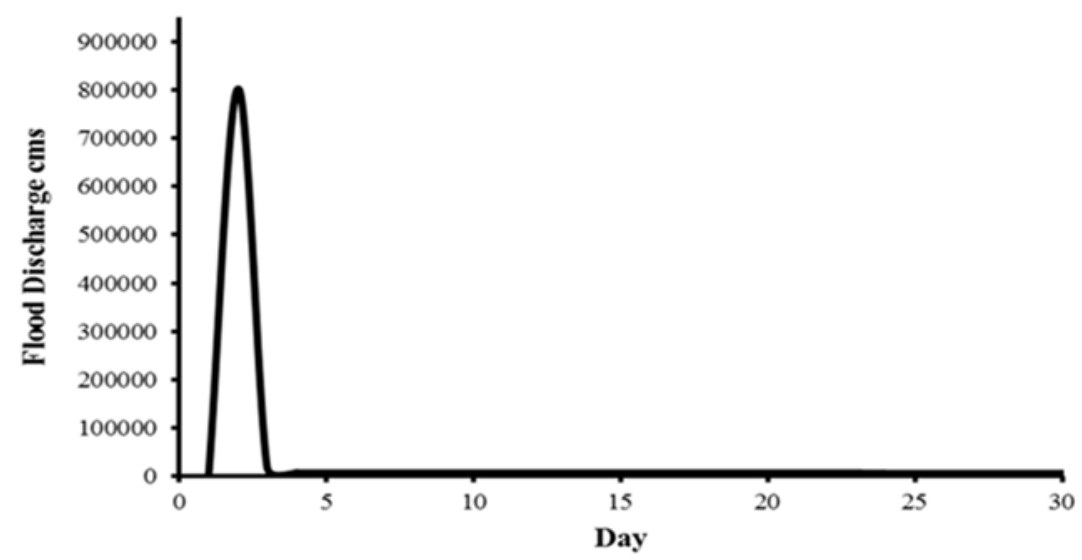

Fig 7 Flood hydrograph due GERD break just D.S. Dam, (Idress et al., 2018)

\section{SIMULATION ASSUMPTIONS}

The debris presented in the GERD, Rosaries, Sennar and Merowe dams that may obstruct the vents during the passage of the flood wave, are assumed absent. All the gates of dam were opened when the flood wave reaches them. Erosion did not take place during the simulations. The lateral flow-off from White Nile and Atbara River worked with their maximum capacity during the flood.

\section{RESULTS AND DISCUSSION}

The hypothetical break of GERD caused huge damage along the Blue Nile and the Nile River from Khartoum to AHD. The Rossiers dam flow in operation case is ranged from 8000 to $5000 \mathrm{~m} 3 / \mathrm{s}$ and maximum upstream measured water level was $470 \mathrm{~m}+\mathrm{msl}$. The GERD break 
flood increased the inflow to $54000 \mathrm{~m} 3 / \mathrm{s}$ as a peak value and, the water level at upstream Rossiers Dam to $498 \mathrm{~m}+\mathrm{msl}$ with $28 \mathrm{~m}$ over the maximum operation level. The Sennar Dam maximum inflow is between 9900 to $6000 \mathrm{~m} 3 / \mathrm{sec}$ with maximum upstream measured water level of $420 \mathrm{~m}+\mathrm{msl}$. GERD break increased the inflow to Sennar Reservoir to be $40000 \mathrm{~m} 3 / \mathrm{s}$ and upstream water level to $435 \mathrm{~m}+\mathrm{msl}$ as a peak value. The GERD break flood increased the water level at the Merowe Dam to $281 \mathrm{~m}+\mathrm{msl}$ as a peak water stage while the operational stage is $270 \mathrm{~m}+\mathrm{msl}$. The AHD Reservoir inflow increass to $42000 \mathrm{~m} 3 / \mathrm{s}$ after 26 day from start GERD break. Many cities in Sudan faces a catastrophic effect due to GERD break as shown in Fig 8 and tabulated in Table 1. ARC-GIS software was employed to develope inundation maps for the study area as shown in Fig(s) 9, 10, 11 and 12.

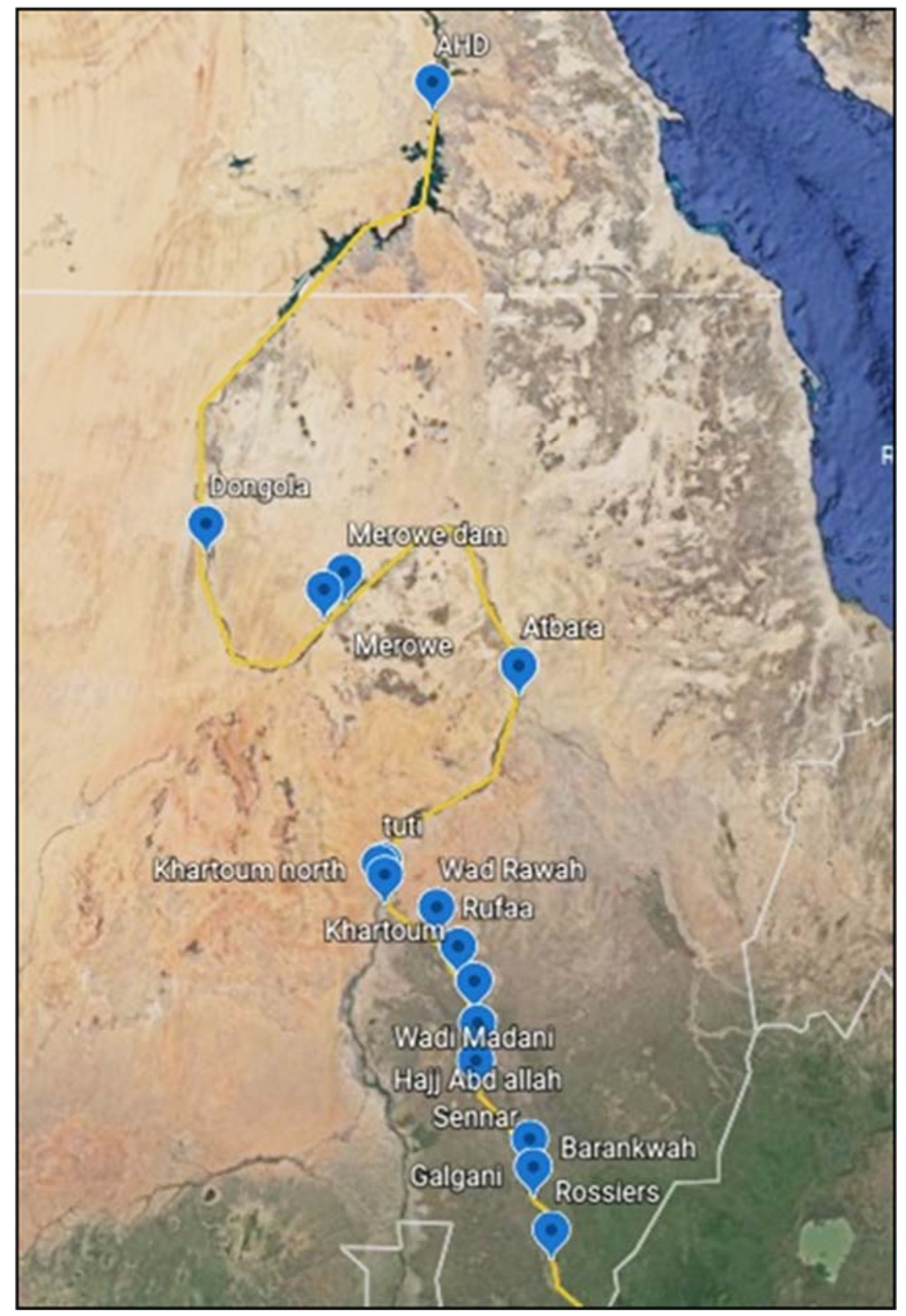

Fig 8 Main Sudan cities along study area 
INUNDATION HAZARDS ON NILE DOWNSTREAM COUNTRIES DUE TO GERD BREAK

Table 1 Flood depth and time arrival due GERD

\begin{tabular}{|c|c|c|c|c|c|}
\hline Name & $\begin{array}{c}\text { distance } \\
\text { from GERD } \\
(\mathrm{Km} .)\end{array}$ & $\begin{array}{l}\text { lag time } \\
\text { (day) }\end{array}$ & $\begin{array}{c}\text { initial water } \\
\text { level } \\
(\mathrm{m}+\mathrm{msl})\end{array}$ & $\begin{array}{c}\text { peak water } \\
\text { level } \\
(\mathrm{m}+\mathrm{msl})\end{array}$ & $\begin{array}{l}\text { flooded depth } \\
\text { (m) }\end{array}$ \\
\hline Rossiers & 110 & 1 & 468.5015 & 498.0259 & 29.5244 \\
\hline Galgani & 200 & 1 & 423.8505 & 465.6467 & 41.7962 \\
\hline Barankwah & 250 & 1 & 417.5677 & 457.2323 & 39.6646 \\
\hline Sennar & 430 & 2 & 413.3019 & 434.2141 & 20.9122 \\
\hline Hajj Abd allah & 500 & 3 & 402.9133 & 425.8674 & 22.9541 \\
\hline Wadi Madani & 595 & 4 & 387.8125 & 414.8963 & 27.0838 \\
\hline Ruffa & 650 & 4 & 380.2402 & 405.493 & 25.2528 \\
\hline Wadi Rawah & 702 & 6 & 378.2999 & 394.775 & 16.4751 \\
\hline Khartoum & 751 & 6 & 378.4842 & 395.199 & 16.7148 \\
\hline totti & & 6 & 377.4325 & 394.08 & 16.6475 \\
\hline Khartoum & 800 & 6 & 378.1312 & 394.3866 & 16.2554 \\
\hline Abd alkader & 851 & 7 & 372.8307 & 386.6921 & 13.8614 \\
\hline Attbra & 1100 & 11 & 343.8707 & 360.1598 & 16.2891 \\
\hline Merowe dam & 1550 & 16 & 272.8236 & 281.0992 & 8.2756 \\
\hline Merowe & 1600 & 17 & 252.162 & 267.0162 & 14.8542 \\
\hline Dongola & 1848 & 21 & 215.5586 & 232.8488 & 17.2902 \\
\hline AHD & & 26 & 174.8004 & 174.8058 & 0.0054 \\
\hline
\end{tabular}




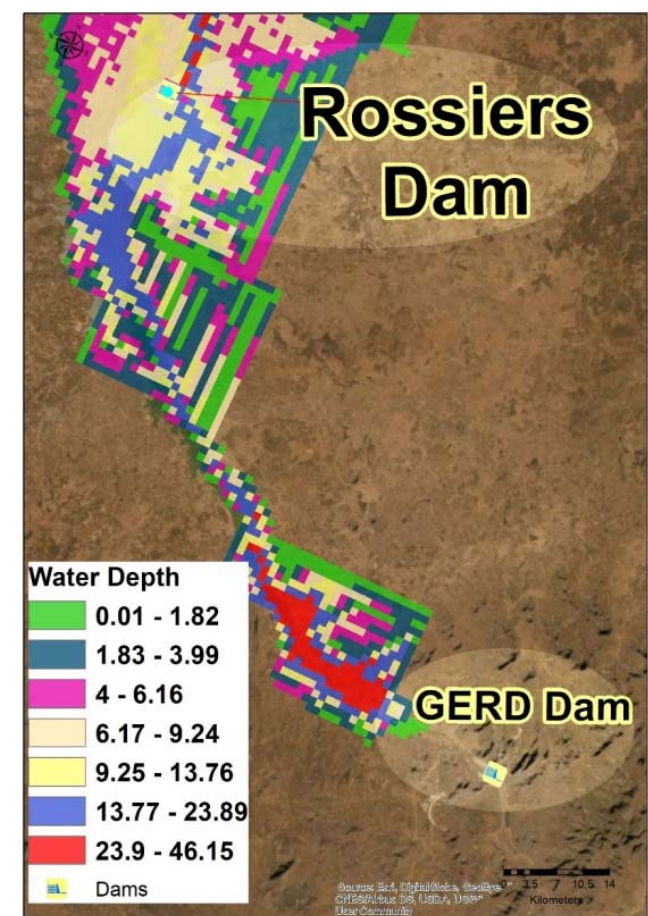

Fig 9 Inundation map from GERD to Rossieres dam

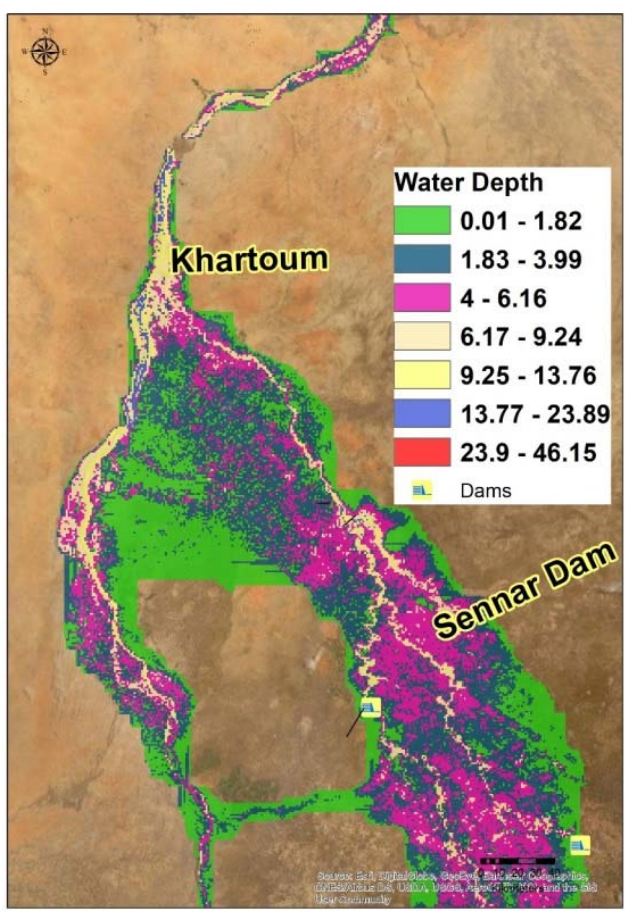

Fig 11 Inundation map from Khartoum to Merowe dam city

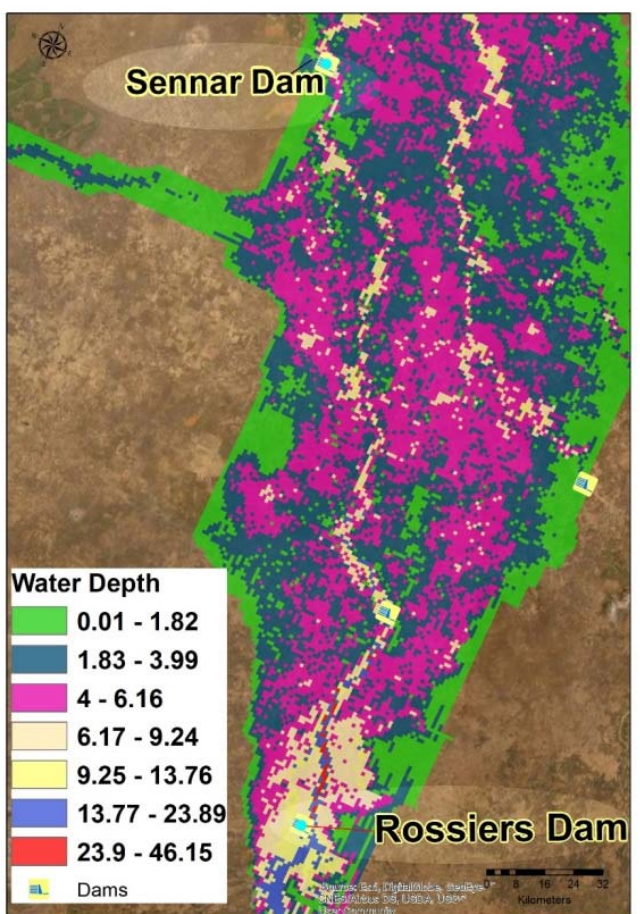

Fig 10 Inundation map from Rossieres Dam to Senar dam

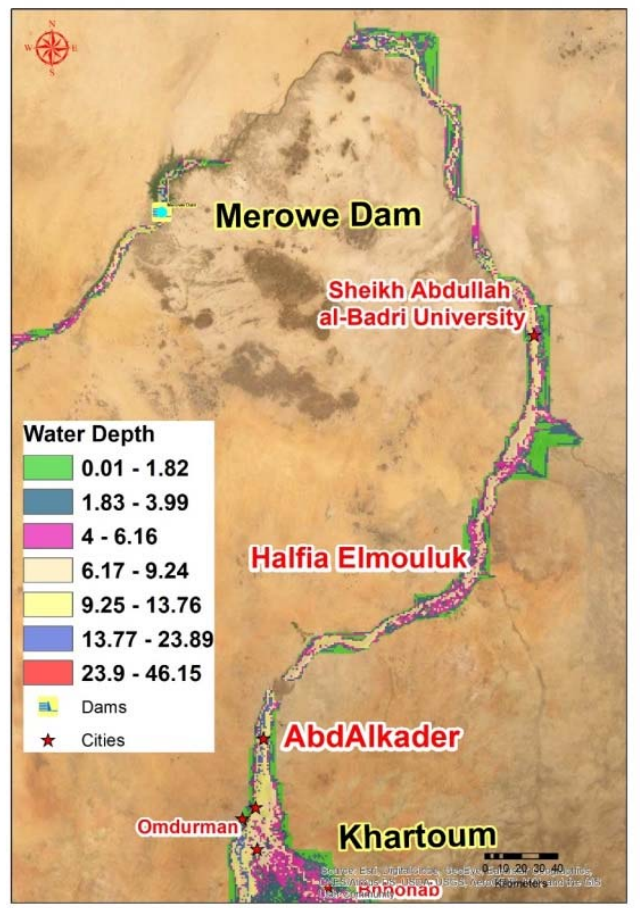

Fig 12 Inundation map from Senar dam to Khartoum city 


\section{CONCLUSIONS}

GERD break simulation revealed that the average hourely peak outflow is about approximately $2300000 \mathrm{~m} 3 / \mathrm{s}$ within $5 \mathrm{hr}$ from the beginning of GERD break. In addition, the average daily peak inflow at the entrance of Lake Nasser approachs $42000 \mathrm{~m} 3 / \mathrm{s}$ after 26 days from the beginning of GERD break. The inflow to Lake Nasser is about three times of the maximum inflow at wet seasons (maximum recorded peak inflow at wet season was about $13000 \mathrm{~m} 3 / \mathrm{s}$ ). So, it may be harmful to the AHD without precaution measures like lowering the crest level of touska spillway, and this needs more investigations. Also, the numerical results showed that Rosaries, Sennar, and Merowe dams are coverd by GERD break flood. Moreover, Al Khartoum city is flooded by a water depth of about $17 \mathrm{~m}$ above the land level. The GERD break floodwater is arrived Al Khartoum city within 6 days from the beginning of dam break. So that, many infrastructures in Sudan like universities, roads, railways, hospitals, airports, schools, farms and factories, etc. are faced catastrophic destruction due to GERD break.

\section{REFERENCES}

[1] Abdelhaleem, F., Ibrahim, S. A. S., \& El-Belasy, A. (2011). Prediction of breach formation through the Aswan High Dam and subsequent flooding downstream. Nile Basin Water Science \& Engineering Journal, 4(1), 99-111.

[2] Ali, Y. S. A. (2014). The Impact of Soil Erosion in the Upper Blue Nile on Downstream Reservoir Sedimentation.

[3] Asnaashari, A., Meredith, D. and, \& Scruton, M. (2013). Dam breach inundation analysis using hec-ras and gis two case studies in british columbia, canada Ahmad. Journal of Chemical Information and Modeling, 53(9), 1689-1699.

[4] El Bastawesy, M., Gabr, S., \& Mohamed, I. (2015). Assessment of hydrological changes in the Nile River due to the construction of Renaissance Dam in Ethiopia. Egyptian Journal of Remote Sensing and Space Science, 18(1), 65-75.

[5] https://doi.org/10.1016/j.ejrs.2014.11.001

[6] Idress, M. I., Abdelhaleem, F. and, \& Idress, M. I. (2018). Prediction of Flood Hydrograph due to Grand Ethiopian Renaissance Dam Break. Twenty-First International Water Technology Conference, IWTC21, July, 28-30.

[7] Juliastuti, \& Setyandito, O. (2017). Dam break analysis and flood inundation map of Krisak dam for emergency action plan. AIP Conference Proceedings, 1903(November 2017). https://doi.org/10.1063/1.5011615

[8] Khosravi, K., Rostaminejad, M., Cooper, J. R., Mao, L., \& Melesse, A. M. (2019). Dam break analysis and flood inundation mapping: The case study of Sefid-Roud Dam, Iran. Extreme Hydrology and Climate Variability: Monitoring, Modelling, Adaptation and Mitigation, April, 395-405. https://doi.org/10.1016/B978-0-12815998-9.00031-2

[9] Mahdi, S. (2007). Dam Break Modelling And Flood Wave Propagation In Urban Area: The Bovilla Dam. In UNESCO-IHE Institute for Water Education, Delft, the Netherlands (Issue May).

[10] Sayed, S. M. El, Hamed, K., Asfaw, G., Seleshi, Y., Ahmed, A. E., Deyab, D. H., Yon, B., Roe, J. D. N., Failer, E., Failer, E., \& Basson, T. (2013). international panel of experts for ethiopian renaissance dam final report.

[11] Shahin, M. (1985). Hydrology of the Nile Basin. In Hydrology of the Nile Basin. https://doi.org/10.1016/0022-1694(87)90079-5

[12] Soliman, A. H., El Zawahry, A., \& Bekhit, H. (2019). GERD Failure Analysis and the Impacts on Downstream Countries. Handbook of Environmental Chemistry, 79, 149171. https://doi.org/10.1007/698_2017_135 
[13] Sutcliffe, J. V., \& Parks, Y. P. (1999). The hydrology of the Nile. The Hydrology of the Nile. IAHS Special Publication No.5., 5(5).

[14] Tesfa, B. C. (2013). Benefit of Grand Ethiopian Renaissance Dam Project (GERDP) for Sudan and Egypt. EIPSA Communicating Article: Energy, Water, Environment I\& Economic, 1(1), 1-12. www.eipsa1.com/cms/articles/BenefitofGERDP.pdf 